\title{
Comparison of Ground-Measured and Image-Classified Mesquite (Prosopis glandulosa) Canopy Cover
}

\author{
Mustafa Mirik ${ }^{1}$ and R. James Ansley ${ }^{2}$ \\ Authors are ${ }^{1}$ Associate Research Scientist and ${ }^{2}$ Professor, Texas AgriLife Research, Vernon, TX 76385, USA.
}

\begin{abstract}
Remote sensing has long been recognized as a rapid, inexpensive, nondestructive, and synoptic technique to study rangeland vegetation and soils. With respect to the worldwide phenomenon of woody plant invasion on many grasslands and rangelands, there is increasing interest in accurate and cost-effective quantification of woody plant cover and distribution over large land areas. Our objectives were to 1) investigate the relationship between ground-measured and image-classified honey mesquite (Prosopis glandulosa Torr.) canopy cover at three sites in north Texas using high spatial resolution (0.67-m) aerial images, and 2) examine the suitability of aerial images with different spatial resolutions $(0.67-\mathrm{m}, 1-\mathrm{m}$, and 2-m) for accurate estimation of mesquite canopy cover. The line intercept method and supervised maximum likelihood classifier were used to measure mesquite cover on the ground and on images, respectively. Images all were taken in September when mesquite foliage was photosynthetically active and most herbaceous vegetation was dormant. The results indicated that there were robust agreements between classified and ground-measured mesquite cover at all three sites with the coefficients of determination $\left(r^{2}\right) \geq 0.95$. Accuracy of lower spatial resolution images ranged from $r^{2}=0.89-0.93$, with the 2-m spatial resolution image on one of the sites at $r^{2}=0.89$. For all sites, the overall, producer's, and user's accuracies, and kappa statistics were $92 \%$ and $97 \%, 91 \%$ and $99 \%, 85 \%$ and $96 \%$, and 0.82 and 0.95 for $2-\mathrm{m}$ and $0.67-\mathrm{m}$ spatial resolution images, respectively. Results showed that images at all three spatial resolution levels were effective for estimating mesquite cover over large and remote or inaccessible areas.
\end{abstract}

\section{Resumen}

La técnica de sensores remotos ha sido reconocida como una técnica rápida, económica, no destructiva, y sinóptica para el estudio de la vegetación de los pastizales y suelos. Con respecto al fenómeno mundial de invasión de plantas leñosas praderas y pastizales, existe un creciente de interés en la cuantificación precisa y efectiva en costo, del alcance y distribución de las plantas leñosas en grandes extensiones de tierra. Nuestros objetivos fueron: 1) investigar la relación entre la medición en tierra y la clasificación de imágenes de la cobertura del mezquite (Prosopis glandulosa Torr), en tres sitios al norte de Texas, usando imágenes de alta resolución espacial $(0.67-\mathrm{m})$, y 2) examinando las imágenes aéreas más apropiadas con diferentes resoluciones espaciales $(0.67-\mathrm{m}, 1-\mathrm{m}$ y $2-\mathrm{m})$ para una exacta estimación de la cobertura del mezquite. Se usaron el método de la línea de intercepción y el clasificador de máxima probabilidad para medir la cubierta del mezquite en el suelo en las imágenes respectivamente. Todas las imágenes se tomaron en Septiembre cuando el follaje del mezquite estaba fotosintéticamente activo y la mayoría de la vegetación herbácea perennes estaba inactiva. Los resultados indicaron que hubo sólidos coincidencias entre las medidas clasificadas y las del suelo en la medida de cobertura del mezquite en todos los sitios con coeficientes de determinación $\left(r^{2}\right) \geq 0.95$. La precisión de las imágenes espaciales de menor resolución, varían entre $r^{2}=0.89-0.93$, con 2-m de resolución espacial de imagen en uno de los sitios a $r^{2}=0.89$. En todos los sitios, en general, las cifras de precisión de los productores y usuarios y las estadísticas de kappa fueron $92 \%$ y $97 \%$, 91\% y 99\%, 85\% y 96\%, y 0.82 y 0.95 para 2 -m y 0.67 -m en imágenes de resolución espacial, respectivamente. Los resultados mostraron que las imágenes en los tres niveles de resolución espacial fueron efectivas en la estimación de la cobertura del mezquite en áreas grandes, remotas o inaccesibles.

Key Words: aerial images, brush management, rangeland vegetation, remote sensing, woody plant invasion

\section{INTRODUCTION}

It is important to quantify areas occupied by invasive woody plants on rangelands in order to determine the ecological and economic impacts of the invasion as well as the feasibility of management activities designed to reduce woody plant cover. The general distribution of the invasive legume, mesquite (Prosopis spp.) has been documented in many regions of the world, including the southwestern United States (Smith and Rechenthin

\footnotetext{
Correspondence: Mustafa Mirik, Texas AgriLife Research, PO Box 1658, 11708 Highway 70 South, Vernon, TX 76385, USA. Email: mmirik@ag.tamu.edu

Manuscript received 5 May 2011; manuscript accepted 10 September 2011.
}

1964; Martin and Turner 1977; Browning et al. 2008), South America (Cabral et al. 2003), Australia (van Klinken and Campbell 2001; Robinson et al. 2008), southern Africa (MacDonald 1989), and India (Sharma and Dakshini 1991). Land area covered by honey mesquite (Prosopis glandulosa Torr.) is estimated to exceed 21 million ha in Texas alone (SCS 1988). However, the specific spatial distribution and degree of coverage of this and other invasive shrubs over large land areas is not well quantified. Much of the existing information includes either surveys in which mesquite stands are placed into generalized cover classes (e.g., 1-10\%; Smith and Rechenthin 1964; SCS 1988), or summaries of areas either occupied (at any density or cover) or not occupied by mesquite (Buffington and Herbel 1965). Some studies 
have quantified changes in mesquite cover for specific sites (Archer et al. 1988; Warren et al. 1996; Browning et al. 2008; Ansley et al. 2001, 2010).

Determining the distribution and spread of woody plant populations on rangelands is often difficult with ground surveys because of the extensive land area involved, time and labor required, and inaccessibility of many areas (Andersen 2006; Marsett et al. 2006). Therefore, remote sensing has received considerable attention in rangeland ecology and management as a rapid, inexpensive, and nondestructive method for assessing vegetation distribution, especially on inaccessible and complex geographic terrains. It is a tool that provides several advantages, including a synoptic view, cost effectiveness, multitemporal coverage, and multispectral and hyperspectral data (Joshi et al. 2004).

A wide range of sensor systems, including aerial photographs, airborne and satellite multispectral and hyperspectral sensors, ground-based instruments, and other spatial information technologies, have been successful for mapping distribution of certain species (Byers et al. 2002; Joshi et al. 2004). Successful discrimination is linked to differences in reflectance properties among species, which often are due to differences in phenological characteristics at certain time periods (Anderson et al. 1996; Medlin et al. 2000; van Klinken et al. 2007; Yang et al. 2009). For example, mesquite growing in grasslands often can be separated from surrounding vegetation in the late summer when grasses are dormant and mesquite is still green (Ansley et al. 2001). There is a need to determine accuracy of remotely sensed determination of woody plant cover on rangelands with ground-measured data.

Most methods used for the verification of classified images involve determining whether or not a particular point or pixel is classified correctly (Everitt et al. 2007; Yang et al. 2009; Mirik et al. 2011). This involves either physically locating a point in the field or locating a point on an image, visually determining what the classification should be at that point, and then comparing it to what the classification process has determined. With respect to verification data for classified image variables that are not point-specific, such as percent canopy cover, the ground and classified image can be compared through a regression model. Because it is nearly impossible to determine in the field the exact percent canopy cover of large masses of vegetation (i.e., shrubs and trees) over any land area more than a few square meters, methods of subsampling such as the line intercept method by Canfield (1941) have been employed to provide a plot-level field estimate of canopy cover (e.g., Davies et al. 2010). Few studies have used this method of determining canopy cover in the field as verification for classified images of canopy cover through regression analysis (Kadmon and Harari-Kremer 1999). In addition, the resulting regression model also will allow for an inexpensive and accurate prediction of cover with minimal labor requirements for the future needs. Our objectives were to 1 ) investigate the relationship between ground-measured and aerial imageclassified honey mesquite canopy cover at three sites in north Texas using high spatial resolution $(0.67-\mathrm{m})$ images, and 2) examine the suitability of aerial images with different spatial resolutions $(0.67-\mathrm{m}, 1-\mathrm{m}$, and $2-\mathrm{m})$ for accurate estimation of mesquite canopy cover.

\section{METHODS}

The study was conducted on three sites in Wilbarger County in north Texas (Site 1: North Walker Pasture, lat $34^{\circ} 03^{\prime} \mathrm{N}$, long $99^{\circ} 24^{\prime} \mathrm{W}$, elevation: $355 \mathrm{~m}$; Site 2: Gin Pasture, lat $33^{\circ} 53^{\prime} \mathrm{N}$, long $99^{\circ} 21^{\prime} \mathrm{W}$, elevation: $380 \mathrm{~m}$; Site 3: Ninemile Pasture, lat $33^{\circ} 85^{\prime} \mathrm{N}$, long $99^{\circ} 42^{\prime} \mathrm{W}$, elevation: $378 \mathrm{~m}$; Table 1). Areas were 793, 651, and 197 ha for Sites 1-3, respectively. Annual total precipitation at the sites is $660 \mathrm{~mm}$, bimodally distributed with peak months in May and September. Average annual air temperature is $24^{\circ} \mathrm{C}$ with peak summer temperatures of $40^{\circ} \mathrm{C}$ to $42^{\circ} \mathrm{C}$ and low winter temperatures of $-10^{\circ} \mathrm{C}$ to $-12^{\circ} \mathrm{C}$. Each site is dominated by a honey mesquite woody overstory with a second woody species, lotebush (Ziziphus obtusifolia var. obtusifolia [Hook. ex. T. \& A. Gray] A. Gray) occurring infrequently $(<1 \%$ canopy cover). Herbaceous species at all three sites consist of a mixture of $\mathrm{C}_{3}$ perennial midgrasses and $\mathrm{C}_{4}$ mid- and short grasses. Tulip pricklypear (Opuntia phaeacantha Engelm.) and tasajillo (Opuntia leptocaulis DC.) are common at the sites. Soils at Site 1 are fine, mixed, superactive, thermic Typic Paleustalfs of the Wichita series, which are very deep, well-drained, moderately slowly permeable soils with $0-5 \%$ slopes. Soils at Site 3 are fine, mixed, superactive, thermic Vertic Paleustolls of the Tillman series, which are very deep, well-drained, slowly permeable soils with $0-1 \%$ slopes. Soils at Site 2 are a mixture of Wichita and Tilman soils.

Images used to classified mesquite coverage for Objective 1 were color infrared aerial photos taken at a nominal scale of 1:5 000 on 29 September 2002 for Site 1 and 3 September 2000 for Sites 2 and 3 with a Piper Aztec twin-engine N4699P airplane at a flight altitude $760 \mathrm{~m}$ from the ground level (Table 1). Aerial photos were acquired using a Leica RC30 aerial film camera equipped with a Leica Universal Aviogon for second generation (UAG/4S) lens (Leica Geosystems Inc, Norcross, GA). Eastman Kodak 2443 color infrared-false color reversal and 1443 color infrared films were used in 2000 and 2002, respectively. The aerial photos were scanned into images using an EPSON Expression 1600 scanner (Seiko Epson Corporation, Long Beach, CA) and yielded a $0.67-\mathrm{m}$ spatial resolution (hereafter $0.67-\mathrm{m}$ image) with a file size below 13 megabytes scanner setting.

For objective 2, two county-level color infrared aerial images of Wilbarger County were downloaded from the National Agricultural Imagery Program (NAIP) provided by the Natural Resources Conservation Service Geospatial Data Gateway ${ }^{1}$ and compared to the $0.67-\mathrm{m}$ aerial image. The NAIP images included a four-band digital aerial photographic image with a spatial resolution of 1-m (hereafter 1-m image) taken on 27 September 2008, and a three-band digital ortho-image with a spatial resolution of 2-m (hereafter 2-m image) taken on 13 September 2006 (Table 1). The NAIP images were acquired with a Leica airborne digital sensor ADS40-II SH52 that was flown with a Cessna Conquest-II turboprop airplane. The flight altitudes from the ground level were about $7.6 \mathrm{~km}$ and $9 \mathrm{~km}$ for 1-m and for 2-m images, respectively (S. McIff, USDA, personal communication, August 2011). Both NAIP images were projected to the Universal Transverse Mercator North

${ }^{1}$ http://datagateway.nrcs.usda.gov/ 
Table 1. Summary of field-measured and image-classified mesquite canopy cover (\%), site, and image characteristics used in this study. Information for the 1-m and 2-m National Agricultural Imagery Program (NAIP) images was provided by S. Mclff, USDA, in August 2011. ${ }^{1}$

\begin{tabular}{|c|c|c|c|c|c|c|c|}
\hline & \multicolumn{3}{|c|}{ Site 1} & \multicolumn{3}{|c|}{ Site 2} & \multirow[t]{2}{*}{ Site 3} \\
\hline & \multicolumn{6}{|c|}{ Image used ${ }^{2}$} & \\
\hline & $0.67-m$ & $1-m$ & $2-m$ & $0.67-m$ & $1-m$ & $2-m$ & $0.67-\mathrm{m}$ \\
\hline Mean (field \% cover) & 53.4 & 55.44 & 55.44 & 36.4 & 44.17 & 44.42 & 46.5 \\
\hline Mean (image \% cover) & 51.2 & 57.49 & 58.77 & 37.68 & 48.35 & 47.15 & 47.12 \\
\hline SE (field) & 4.5 & 4.4 & 4.4 & 4.01 & 4.57 & 4.19 & 3.16 \\
\hline SE (image) & 3.9 & 4.7 & 5.12 & 3.5 & 4.85 & 3.14 & 3.36 \\
\hline $\mathrm{N}$ & 31 & 35 & 35 & 24 & 19 & 22 & 24 \\
\hline Latitude & $34^{\circ} 03^{\prime} \mathrm{N}$ & & & $33^{\circ} 53^{\prime} \mathrm{N}$ & & & $33^{\circ} 85^{\prime} \mathrm{N}$ \\
\hline Longitude & $99^{\circ} 24^{\prime} \mathrm{W}$ & & & $99^{\circ} 21^{\prime} \mathrm{W}$ & & & $99^{\circ} 42^{\prime} W$ \\
\hline Elevation (m) & 355 & & & 380 & & & 378 \\
\hline \multicolumn{8}{|l|}{ Image characteristic } \\
\hline Acquisition date & $\begin{array}{l}29 \text { September } \\
2002\end{array}$ & $\begin{array}{l}27 \text { September } \\
2008\end{array}$ & $\begin{array}{l}13 \text { September } \\
2006\end{array}$ & $\begin{array}{l}3 \text { September } \\
2000\end{array}$ & $\begin{array}{l}27 \text { September } \\
2008\end{array}$ & $\begin{array}{l}13 \text { September } \\
2006\end{array}$ & $\begin{array}{l}3 \text { September } \\
2000\end{array}$ \\
\hline Number of band & 3 & 4 & 3 & 3 & 4 & 3 & 3 \\
\hline Flight height (m) & 760 & 7600 & 9000 & 760 & 7600 & 9000 & 760 \\
\hline Camera/Sensor & $\mathrm{RC} 30$ & ADS40-II SH52 & ADS40-II SH52 & RC30 & ADS40-II SH52 & ADS40-II SH52 & RC30 \\
\hline Lens & UAG/4S & & & UAG/4S & & & UAG/4S \\
\hline Film & $1443-\mathrm{CIR}$ & & & 2443-CIR & & & 2443-CIR \\
\hline
\end{tabular}

${ }^{1} \mathrm{SE}$ indicates standard error; $\mathrm{N}$, number of samples.

${ }^{2} 0.67-\mathrm{m}, 1-\mathrm{m}, 2-\mathrm{m}$ indicate $0.67-\mathrm{m}, 1-\mathrm{m}$, and 2 meter spatial resolution images, respectively.

American Datum 1983 Zone 14 North by the provider. The 0.67-m aerial images were georeferenced to the 1-m NAIP aerial image using easily identifiable locations (e.g., trees, road corners, water ponds) on the images by employing an image-toimage registration method in Environment for Visualizing Images software (ENVI; ITT Visual Information Solution, Boulder, CO).

Mesquite cover was measured on the ground using the line intercept method (Canfield 1941). Thirty-one, 24, and 24 plots were established at Sites 1, 2, and 3, respectively, to quantify mesquite canopy cover as part of other studies (Ansley et al. 2003; Ansley and Castellano 2006). Each plot consisted of 2 or 3 parallel line transects, with each line $20 \mathrm{~m}, 30 \mathrm{~m}$, or $60 \mathrm{~m}$ in length and 5-20 m apart. Mesquite percent cover was measured along each line at Site 1 in 2006, at Site 2 in 19992001, and at Site 3 in 2002. Plot percent cover was the average of all lines per each plot. Because of differences in some of the dates between when ground cover was measured and when aerial images were taken, ground cover values on some data sets were adjusted up or down by 1 percent per year, based on previously determined annual rates of mesquite canopy cover increases for the region (Ansley et al. 2001). At Site 2, smallscale wildfires burned two plots in 2006 and three additional plots in 2007. Therefore, a total of 24, 22, and 19 plots at this site were used for the $0.67-\mathrm{m}, 2-\mathrm{m}$, and 1-m aerial images, respectively. All but four plots were prescribed burned at Site 3 after 2002 as part of another experiment and therefore this site was not used for Objective 2 .

Image classifications were performed using the Maximum Likelihood Classifier (MLC), which is a type of supervised classification technique in ENVI. Supervised classification is a procedure for identifying spectrally similar areas on an image in which the user defines known cover types as "training samples," and then the MLC extrapolates those spectral characteristics to other areas for class identifications (Richards and Jia 2006; Lu and Weng 2007; Castillejo-González et al. 2009; Short 2011). The MLC is based on the assumption that members of each class are normally distributed in an image. Implementation of the MLC involves the estimation of class mean vectors and covariance matrices using training samples of each particular class (Pal and Mather 2004; Richards and Jia 2006). If the assumption of a normal distribution for each class is correct, then the classification has a minimum overall probability of error and the MLC is the optimum choice (Swain and Davis 1978). Therefore, the MLC has been widely used to classify images by the remote sensing community (Short 2011). Training samples consist of groups of individual pixels, polygons, or individual spectra (Richards and Jia 2006; Lu and Weng 2007).

For the classification in this study, 5-20 polygons (depending on the amount of ground cover by each cover type in the images) were arbitrarily selected and manually digitized on the aerial images as the training samples (regions of interest) to represent each respective classes. Each polygon consisted of 10 pixels from easily identifiable cover types on the aerial images: mesquite, grass, water, shadow, bare ground, and cropland; however, the last five classes (grass, water, shadow, bare ground, and cropland) were combined into a nonmesquite class as the final maps (Fig. 1). Image collection started at 1130 hours and ended at 1300 hours with local time for the 0.67- $\mathrm{m}$ images and collection time was around 1200 hours for the 1-m NAIP images; therefore, canopy shadow was minimal in these images. We could not obtain image collection time for 2-m NAIP image, but canopy shading appeared comparable to 

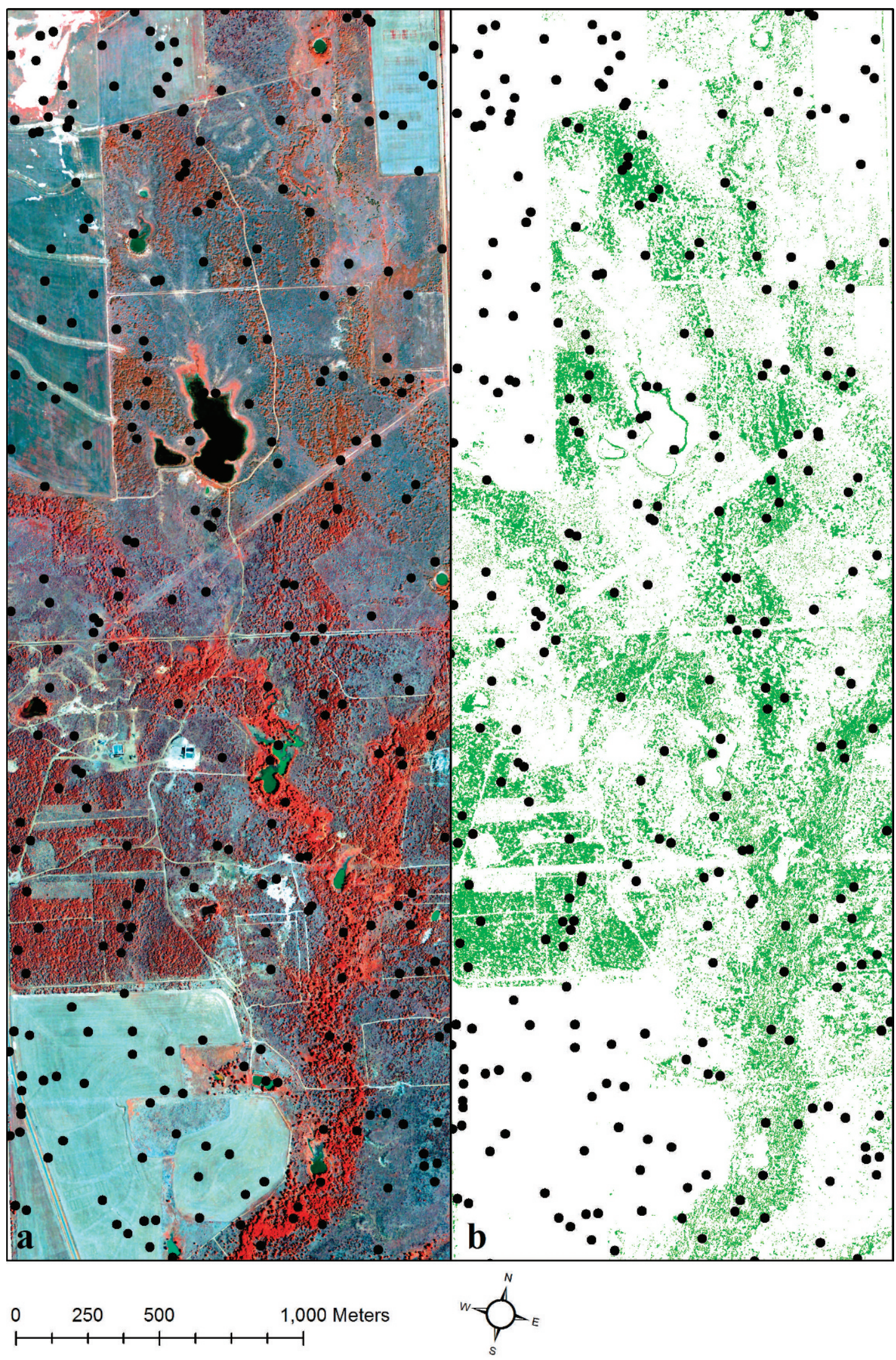

Figure 1. a, Color infrared aerial image with 1-m spatial resolution acquired over Site 1(North Walker Pasture located about $21 \mathrm{~km}$ south of Vernon, TX), which was b, classified using the supervised Maximum Likelihood Classifier (MLC) for honey mesquite distribution shown with green color. Black dots show the 308 locations of validation data points used for accuracy assessment. 

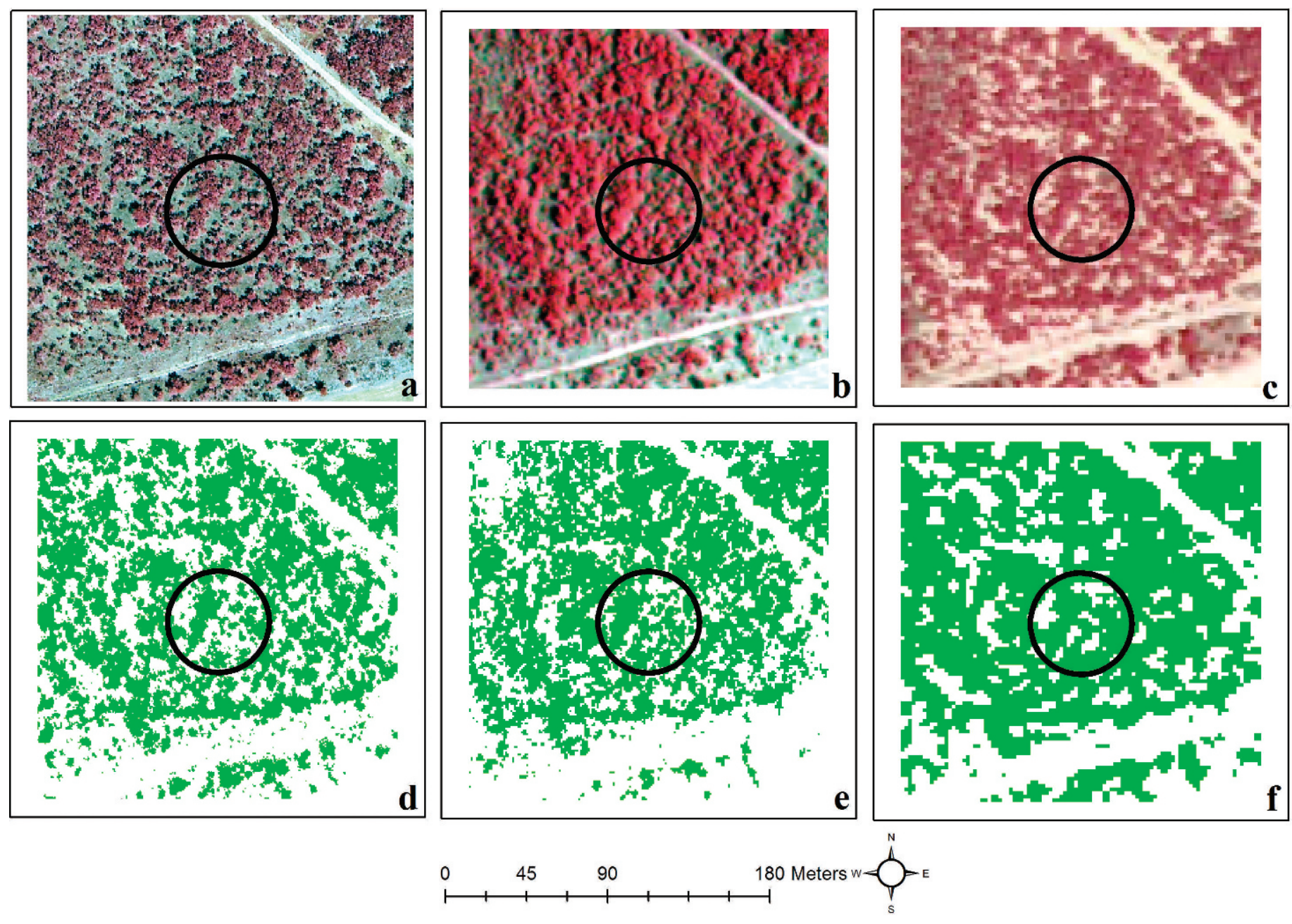

Figure 2. An example of color infrared a, 0.67-m, b, 1-m, and c, 2-m spatial resolution images and classified honey mesquite cover of $\mathbf{d}, 0.67-\mathrm{m}$, e, 1-m, and $\mathbf{f}, 2-\mathrm{m}$ spatial resolution maps with a circle representing one of the study plots. Measurements of mesquite canopy cover in the circle plot were $68 \%, 62 \%, 69 \%$, and $76 \%$ for the line intercept, $0.67-\mathrm{m}, 1-\mathrm{m}$, and $2-\mathrm{m}$ spatial resolution images, respectively.

the 1-m images. For the accuracy assessment, 308 ground verification (reference) points were randomly generated using ArcMap (Fig. 1). The verification points were loaded into a real-time differential Global Positioning System: Trimble GeoXH hand-held computer (Trimble Navigation Ltd, Sunnyvale, CA) equipped with the ArcPad (ESRI, Inc, Redland, CA) software package, and a 4-m external antenna that provides submeter horizontal accuracy $(10 \mathrm{~cm}$; Trimble Navigation Ltd) and were then located on the ground.

Coordinates of starting and ending points of each transect line were taken with a Trimble GeoXH hand-held computer equipped with the ArcPad software package. In ArcMap, circles with the diameters equal to the transect line lengths were created and centered over each plot (Fig. 2). Percentage mesquite cover within each of these bands was calculated by dividing canopy area by total circular area within each band. Regression models were employed to determine the relationship between ground-measured and image-estimated mesquite cover (SigmaStat Software, Inc, Rochester, MN). Classified mesquite cover was set as the independent variable and groundmeasured mesquite cover was set as the dependent variable.

Accuracy assessment for classification was made by constructing the confusion matrix - error matrix or contingency table (Congalton 1991; Lillesand and Kiefer 1994; Congalton and Green 2009). A confusion matrix compares, on a groupby-group basis, the relationship between known actual (reference) categories as verified on the ground and corresponding categories of a classification (Congalton 1991; Lillesand and Kiefer 1994; Congalton and Green 2009). A confusion matrix is a square, with the number of columns and rows being equal to the numbers of categories whose classification accuracy is being evaluated (Lillesand and Kiefer 1994). The overall, user's, and producer's accuracies, and kappa statistics were calculated from the confusion matrix (Congalton 1991; Lillesand and Kiefer 1994; Congalton and Green 2009). The overall accuracy was calculated by dividing the total number of correctly classified pixels (the sum of the elements along the major diagonal-running from upper left to lower right) by total number of reference pixels (Congalton 1991; Lillesand and Kiefer 1994; Congalton and Green 2009). The user's accuracy was calculated by dividing the number of correctly classified pixels in each category by the total number of pixels that were classified in that category (the row total), indicating the probability that a pixel classified into a given category actually represents that category on the ground (Congalton 1991; Lillesand and Kiefer 1994; Congalton and 
Green 2009). The producer's accuracy was calculated by dividing the number of correctly classified pixels in each category (on the major diagonal) by number of training set pixels used for that category (the column total), indicating how well training-set pixels of the given cover types are classified (Congalton 1991; Lillesand and Kiefer 1994; Congalton and Green 2009).

The kappa statistic is a measure of the difference between the actual agreement between classification and reference data and the chance agreement between the classification and reference data. The kappa statistic is an indicator of the extent to which the percentage correct values of an error matrix is due to true agreement versus chance agreement. As true agreement (observed) approaches 1 and chance agreement approaches 0 , the kappa statistic approaches 1, indicating ideal case (Congalton 1991; Lillesand and Kiefer 1994; Congalton and Green 2009).

\section{RESULTS}

\section{Objective 1}

Image-classified mesquite canopy cover values ranged from 8 $100 \%$ at Site $1,10-70 \%$ at Site 2 , and $20-85 \%$ at Site 3 (Table 1). Classified cover on the high-resolution $(0.67-\mathrm{m})$ images predicted ground-measured cover at all three sites with linear regressions $\left(r^{2}>0.95\right.$; Fig. 3$)$. The strongest linear relationship between ground-measured and classified mesquite cover was found at Site $3\left(r^{2}=0.97\right)$. This model also had the lowest standard error of estimate $(\mathrm{SEE}=2.86)$. Slopes of each relationship were maintained near the 1:1 line, indicating a high degree of accuracy throughout the range of cover values in addition to the strong regression relationship.

\section{Objective 2}

Percent mesquite canopy coverage was well-predicted by the classification method at all three aerial image resolution levels for Sites 1 and $2\left(r^{2} \geq 0.89\right.$; Figs. 3 and 4$)$. The lowest variation (about $89 \%$ with a SEE of 4.9 ) in cover was explained by classified cover for Site 2 using the 2-m aerial image, whereas classified covers accounted for $93 \%$ and $95 \%$ of the variability in cover with a SEE of 5.43 and 3.66 using $0.67-\mathrm{m}$ and $1-\mathrm{m}$ aerial images, respectively. About $96 \%$ and $93 \%$ of the variation in cover with an SEE of 4.92 and 6.47 was explained by classified cover using both $0.67-\mathrm{m}$ and $1-\mathrm{m}$ aerial images, respectively, whereas classified cover accounted for $93 \%$ of the variability in cover with a SEE of 6.71 for the Site 1 using the 2-m aerial image.

Overall accuracies for Site 1 were $95 \%, 96 \%$, and $92 \%$ with kappa values of $0.89,0.91$, and 0.82 using the $0.67-\mathrm{m}, 1-\mathrm{m}$, and 2$\mathrm{m}$ images, respectively (Tables 2 and 3). The producer's accuracies for Site 1 were $94 \%, 93 \%$, and $91 \%$ for mesquite and 96, 98, and 93 for nonmesquite, whereas the user's accuracies were $93 \%, 95 \%$, and $87 \%$ for mesquite and $97 \%, 96 \%$, and $95 \%$ for nonmesquite using the $0.67-\mathrm{m}, 1-\mathrm{m}$, and $2-\mathrm{m}$ images, respectively. The overall accuracies for Site 2 were $97 \%, 96 \%$, and $93 \%$ with kappa values of $0.95,0.92$, and 0.85 using the $0.67-\mathrm{m}, 1-\mathrm{m}$, and $2-\mathrm{m}$ images, respectively. The producer's accuracies for Site 2 were $99 \%, 97 \%$, and $94 \%$ for mesquite and $96 \%, 95 \%$, and $91 \%$ for nonmesquite, whereas the user's accuracies were $96 \%, 95 \%$, and $91 \%$ for

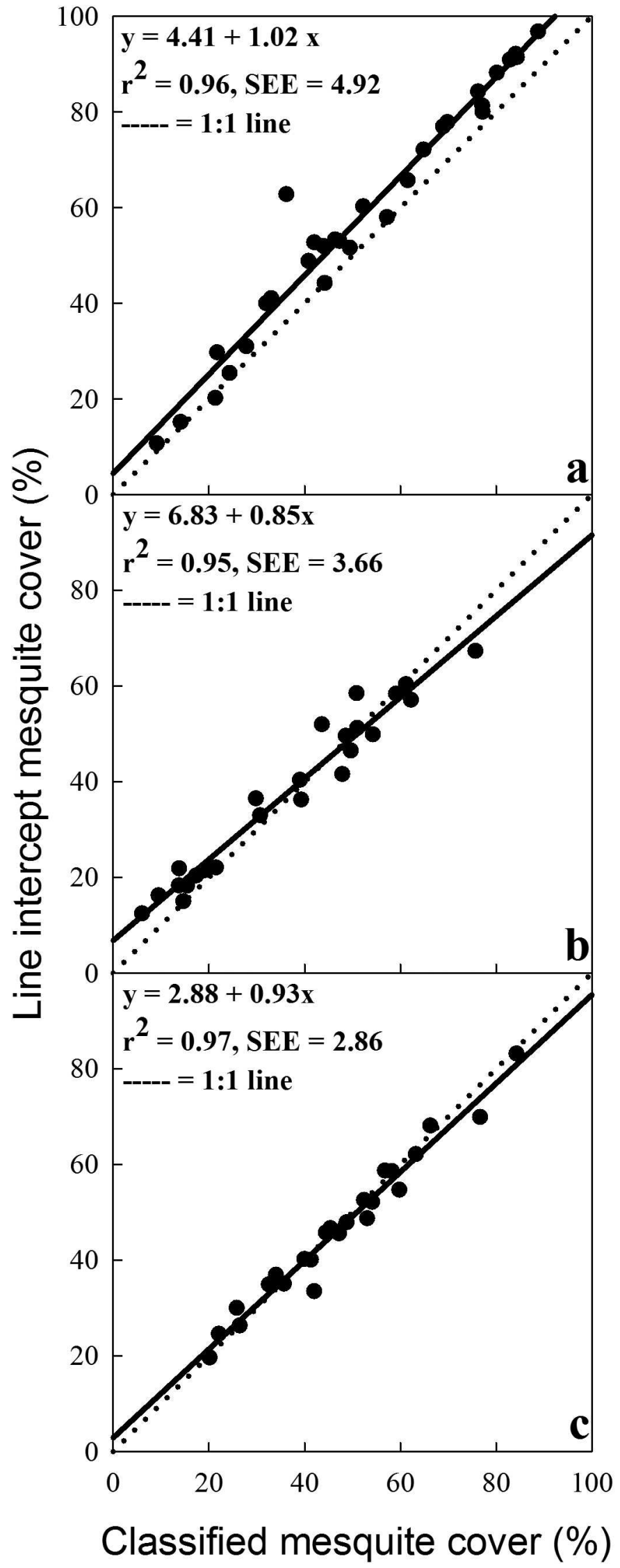

Figure 3. Field measurement of honey mesquite canopy cover plotted against classified canopy cover from aerial images with $0.67-\mathrm{m}$ spatial resolution for a, Site 1, b, Site 2, and $\mathbf{c}$, Site 3 . 


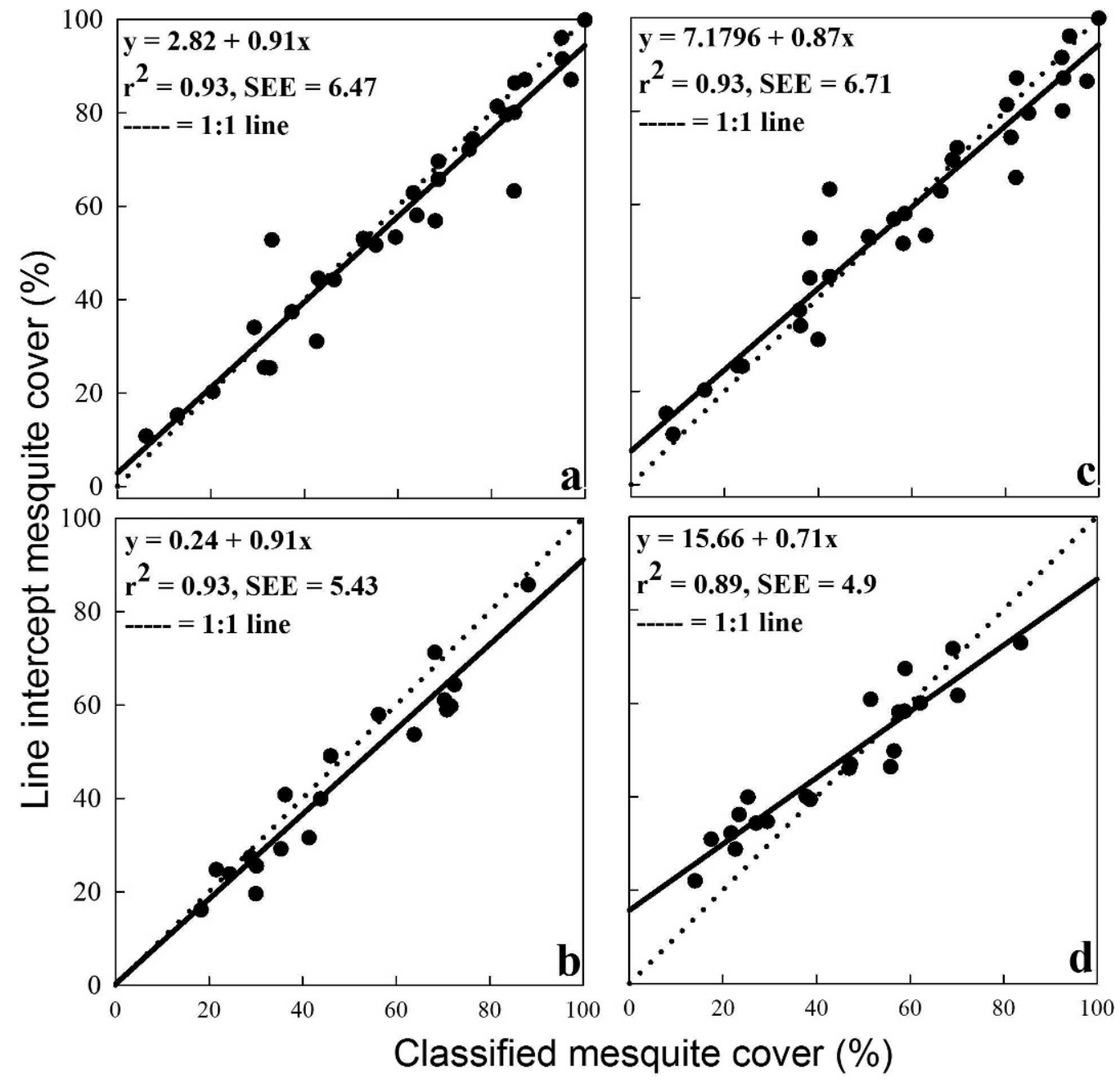

Figure 4. Field measurement of honey mesquite canopy cover plotted against classified canopy cover from aerial images with 1-m spatial resolutions for $\mathbf{a}$, Site 1 and $\mathbf{b}$, Site 2 and 2-m spatial resolution for $\mathbf{c}$, Site 1 and $\mathbf{d}$, Site 2 .

mesquite and $99 \%, 97 \%$, and $94 \%$ for nonmesquite using the $0.67-\mathrm{m}, 1-\mathrm{m}$, and 2-m images, respectively. The overall accuracy for Site 3 was $95 \%$ with a kappa value of 0.88 using the $0.67-\mathrm{m}$ image. The producer's accuracies for Site 3 were $96 \%$ for mesquite and $94 \%$ for nonmesquite, whereas the user's accuracies were 91\% for mesquite and $97 \%$ for nonmesquite using the $0.67-\mathrm{m}$ image.

\section{DISCUSSION}

The major contribution presented in this article is the development of robust simple linear regression models to predict mesquite cover through image classification. The relationships between the classified and ground-measured mesquite cover found here are comparable with other studies for the same or different species $\left(r^{2}=0.94\right.$, Ansley et al. 2003; $r^{2}=0.91$, Asner et al. 2003; $r^{2}=0.91$, Laliberte et al. 2007; $r^{2}=0.98$, Robinson et al. 2008), but were greater than found in other studies $\left(r^{2}=0.80\right.$, Kadmon and Harari-Kremer 1999; $r^{2}=0.64$, Sharp and Bowman 2004). In addition to high classification accuracies, the low SEE found between groundmeasured and classified mesquite cover is further evidence that remotely sensed images could effectively map mesquite populations in the region.

Regarding Objective 2, we found that aerial images with $0.67-\mathrm{m}, 1-\mathrm{m}$, and 2-m spatial resolutions could be used to accurately estimate mesquite cover. Accuracy of the 2-m aerial image was slightly less than those of the $0.67-\mathrm{m}$ and $1-\mathrm{m}$ images. These differences can be attributable to the pixel sizes of the images. For instance, mesquite with canopy area $<4 \mathrm{~m}^{2}$ might not be detected in the $2-\mathrm{m}$ aerial image due to the different canopies being mixed within a pixel or among pixels. Similarly, interstitial nonmesquite space between mesquite trees less than $4 \mathrm{~m}^{2}$ in size might be classified as mesquite (as seen in Fig. 2). Proper or insufficient spatial resolution of remotely sensed images depending on the size of individual plants or canopy patch under investigation is well-known and addressed elsewhere (Ansley et al. 2001; Goslee et al. 2003; Heaton et al. 2003; Laliberte et al. 2007; Browning et al. 2008, 2009). These studies found that the correlation between estimates of woody plant cover from image classification and ground-based measurements depends strongly on the image resolution and the size of the plants under surveillance. Laliberte et al. (2007) found that only $29 \%$ of shrubs with canopy areas $<2 \mathrm{~m}^{2}$ in 
Table 2. Confusion matrix for the maximum likelihood classifier generated from the reference and classified data using the $0.67-\mathrm{m}$ spatial resolution image of Sites 1-3 for mesquite and nonmesquite cover components.

\begin{tabular}{|c|c|c|c|c|c|}
\hline \multirow[b]{2}{*}{ Site } & \multirow[b]{2}{*}{ Classified data } & \multicolumn{2}{|c|}{ Reference data } & \multirow[b]{2}{*}{ Row total } & \multirow[b]{2}{*}{ User's accuracy (\%) } \\
\hline & & Mesquite & Nonmesquite & & \\
\hline \multirow[t]{6}{*}{1} & Mesquite & 103 & 8 & 111 & 92.79 \\
\hline & Nonmesquite & 7 & 190 & 197 & 96.45 \\
\hline & Column total & 110 & 198 & 308 & \\
\hline & Producer's accuracy (\%) & 93.64 & 95.96 & & \\
\hline & Overall accuracy (\%) & 95.13 & & & \\
\hline & Kappa statistic & 0.89 & & & \\
\hline \multirow[t]{6}{*}{2} & Mesquite & 144 & 6 & 150 & 96.00 \\
\hline & Nonmesquite & 2 & 156 & 158 & 98.73 \\
\hline & Column total & 146 & 162 & 308 & \\
\hline & Producer's accuracy (\%) & 98.63 & 96.30 & & \\
\hline & Overall accuracy (\%) & 97.40 & & & \\
\hline & Kappa statistic & 0.95 & & & \\
\hline \multirow[t]{6}{*}{3} & Mesquite & 114 & 12 & 126 & 90.48 \\
\hline & Nonmesquite & 5 & 177 & 182 & 97.25 \\
\hline & Column total & 119 & 189 & 308 & \\
\hline & Producer's accuracy (\%) & 95.80 & 93.65 & & \\
\hline & Overall accuracy (\%) & 94.48 & & & \\
\hline & Kappa statistic & 0.88 & & & \\
\hline
\end{tabular}

Table 3. Confusion matrix for the maximum likelihood classifier generated from the reference and classified data using the 1-m and 2-m spatial resolution aerial images of Sites 1 and 2 for mesquite and nonmesquite cover components.

\begin{tabular}{|c|c|c|c|c|c|c|}
\hline \multirow[b]{2}{*}{ Site } & \multirow{2}{*}{$\begin{array}{l}\text { Image spatial } \\
\text { resolution }\end{array}$} & \multirow[b]{2}{*}{ Classified data } & \multicolumn{2}{|c|}{ Reference data } & \multirow[b]{2}{*}{ Row total } & \multirow[b]{2}{*}{ User's accuracy (\%) } \\
\hline & & & Mesquite & Nonmesquite & & \\
\hline \multirow[t]{6}{*}{1} & $1-m$ & Mesquite & 103 & 5 & 108 & 95.37 \\
\hline & & Nonmesquite & 8 & 192 & 200 & 96.00 \\
\hline & & Column total & 111 & 197 & 308 & \\
\hline & & Producer's accuracy (\%) & 92.79 & 97.46 & & \\
\hline & & Overall accuracy (\%) & 95.78 & & & \\
\hline & & Kappa statistics & 0.91 & & & \\
\hline \multirow[t]{6}{*}{2} & $1-m$ & Mesquite & 142 & 8 & 150 & 94.67 \\
\hline & & Nonmesquite & 5 & 153 & 158 & 96.84 \\
\hline & & Column total & 147 & 161 & 308 & \\
\hline & & Producer's accuracy (\%) & 96.60 & 95.03 & & \\
\hline & & Overall accuracy (\%) & 95.78 & & & \\
\hline & & Kappa statistics & 0.92 & & & \\
\hline \multirow[t]{6}{*}{1} & $2-m$ & Mesquite & 96 & 15 & 111 & 86.49 \\
\hline & & Nonmesquite & 10 & 187 & 197 & 94.92 \\
\hline & & Column total & 106 & 202 & 308 & \\
\hline & & Producer's accuracy (\%) & 90.57 & 92.57 & & \\
\hline & & Overall accuracy (\%) & 91.88 & & & \\
\hline & & Kappa statistics & 0.82 & & & \\
\hline \multirow[t]{6}{*}{2} & $2-m$ & Mesquite & 136 & 14 & 150 & 90.67 \\
\hline & & Nonmesquite & 9 & 149 & 158 & 94.30 \\
\hline & & Column total & 145 & 163 & 308 & \\
\hline & & Producer's accuracy (\%) & 93.79 & 91.41 & & \\
\hline & & Overall accuracy (\%) & 92.53 & & & \\
\hline & & Kappa statistics & 0.85 & & & \\
\hline
\end{tabular}


size were classified, whereas $87 \%$ of all shrubs with canopies $>2 \mathrm{~m}^{2}$ were detected using an image with a spatial resolution $0.86-\mathrm{m}$ in southern New Mexico. In contrast, overall classification accuracy for velvet mesquite cover derived from a 1-m spatial resolution image was greater than that from a $0.6-\mathrm{m}$ resolution image (Browning et al. 2009).

Our ability to utilize aerial images for quantifying trends and patterns of woody plant cover largely depends upon a variety of factors (Browning et al. 2009). Spatial, spectral, and radiometric resolutions along with the image scale, image processing methods, atmospheric haze, shadow, terrain effects, angle between the sensor and vegetative layers, relative contrast between vegetative layers and background, canopy architecture, crown size and height, and plant density clearly influence detection capabilities of remotely sensed image (Fensham and Fairfax 2002; Fensham et al. 2002). In cases where canopies of individuals of the same plants or different plants overlap, it cannot be reliably determined from top-down perspective whether a given image object represents one large plant, multiple plants of the same species, or multiple plants of different species (Browning et al. 2009).

Unique phenological, structural, and spectral characteristics of plants species have been sought to separate target species from the surrounding and mosaic of species using image data (Turner et al. 2003; Yang et al. 2009). In our study, images were acquired during the early fall (September) when most of the grass and forb species were senescent yet mesquite was still green. Because mesquite was the only important brush species at the sites, woody species discrimination and identification was avoided during image classification. In a central Texas study, reflectance spectra of honey mesquite, senescing grass, mixed herbaceous plants, and some other woody plants were recorded in late summer using a hyperspectral handheld field spectroradiometer (Yang et al. 2009). Mixed herbaceous plants and senescing grass had considerably higher reflectance than honey mesquite in the visible and lower in the near infrared (NIR) portions of the spectrum. The shift from higher to lower reflectance occurred around $720 \mathrm{~nm}$ (Yang et al. 2009). Similarly, Everitt et al. (2004, 2007) found that reflectance spectra of honey mesquite measured with a multispectral handheld field radiometer was significantly different than that of mixed herbaceous plants including sedges, broad-leaved herbs, and grasses in the visible spectrum on 15 September 2004 and was insignificant in the NIR region where it was significant on 17 August and 3 November 2004. These measurements by Everitt et al. (2004, 2007) and Yang et al. (2009) support our results that classifications were accurate using the MLC.

Another important finding of this paper is the use of freely available NAIP images collected by United States Department of Agriculture-Farm Service Agency-Aerial Photography Field Office (USDA-FSA-APFO; Salt Lake City, UT). Other recent studies also have used NAIP imagery to study sinkhole features (Dinger et al. 2006), land cover change (Zourarakis et al. 2006), rainfall-runoff modeling (Mihalik et al. 2008), estimation of woody browse abundance (Crimmins et al. 2009), playa wetland mapping (Bowen et al. 2010), estimation of western juniper (Juniperus occidentalis Hook. subsp. occidentalis) cover (Davies et al. 2010), and inventory of coastal prairie wetlands (Enwright et al. 2011). Although we demonstrated that NAIP images could be used to map mesquite cover, the results obtained here might not apply to other species, plant communities and/or seasons.

Overall accuracies of mesquite classification were between $92 \%$ and $97 \%$, indicating that $92 \%$ and $97 \%$ of the category pixels were correctly allocated in the classification maps. The kappa range of 0.82-0.95 indicates that achieved classification accuracies were between $82 \%$ and $95 \%$ better than what would be expected from a random assignment of pixels to those categories. The producer's accuracy (range 91-99\%) indicates the probability of the reference pixels being correctly classified. The user's accuracy (range 87-96\%) indicates the probability of the pixels classified actually representing that category on the ground. For example, accuracy assessment using the $0.67-\mathrm{m}$ image classification for Site 1 resulted in a producer's accuracy of $94 \%$ and user's accuracy of $93 \%$ with an overall accuracy of $95 \%$. These results indicate that although we claim that $94 \%$ of the time an area that was mesquite was identified as mesquite, a user of this classification will find this to be true only $93 \%$ of the time. In other words, $7.21 \%$ (100 - user's accuracy) of the area classified as mesquite on the classification map actually belonged to nonmesquite class.

Although there is no set standard for classification accuracy, Foody (2002) recommended an accuracy target of $85 \%$. Thomlinson et al. (1999) set an overall accuracy target of $85 \%$ with no individual class accuracy less than $70 \%$. Overall classification accuracies ranging from $86.0 \%$ to $93.3 \%$ with the user's and producer's accuracies $>84 \%$ were reported for aerial images of velvet mesquite (Prosopis velutina Woot.) in southeastern Arizona (Browning et al. 2008). Everitt et al. (2007) reported the overall accuracies between $80 \%$ and $92 \%$ for the photographic and QuickBird satellite images, respectively, and producer's and user's accuracies $>87 \%$ for Ashe juniper (Juniperus ashei J. Buchholz) in central Texas. Heaton et al. (2003) reported overall, user's, and producer's accuracies of $89 \%, 89 \%$, and $85 \%$, respectively, for classified aerial images of honey mesquite in north Texas.

\section{MANAGEMENT IMPLICATIONS}

We found strong relationships between ground-measured and image-estimated mesquite canopy cover across three image spatial resolution levels. Image-classified mesquite canopy cover without any adjustment or correction can be used to estimate actual mesquite canopy cover in the field through regression analysis. In other words, there is no need to establish ground plots to correct image-classified mesquite canopy cover because image estimates of mesquite canopy cover are sufficient. These results have important implications for the monitoring and assessment of mesquite encroachment into grassland because this species can negatively affect livestock production and can markedly change the ecosystem dynamics, species diversity, and nutrient, water, and carbon cycles.

This study demonstrated that aerial images are useful data sources for mapping honey mesquite. Because 1-m and 2-m aerial images are freely available at county scales for the United States, such classification methods would also be helpful in monitoring larger areas, such as counties and watersheds that 
are not easily mapped by the conventional methods. Therefore, we suggest that this technology and methodology should be considered when both fine- and larger-scale maps are needed for woody plant management and research.

\section{ACKNOWLEDGMENTS}

Betty Kramp, David Jones, and Roy Stanford assisted with field data collection. In addition, many of the images used in this study were made available by the USDA-NRCS.

\section{LITERATURE CITED}

AndeRSEN, G. L. 2006. How to detect desert trees using CORONA images: discovering historical ecological data. Journal of Arid Environments 65:491-511.

Anderson, G. L., J. H. Everitt, D. E. Escobar, N. R. Spencer, and R. J. Andrascik. 1996. Mapping leafy spurge (Euphorbia esula) infestations using aerial photography and geographic information systems. Geocarto International 11:81-89.

Ansley, R. J., and M. J. Castellano. 2006. Strategies for savanna restoration in the southern Great Plains: effects of fire and herbicides. Restoration Ecology 14:420-427.

Ansley, R. J., B. A. Kramp, and D. L. Jones. 2003. Converting mesquite thickets to savanna through foliage modification with clopyralid. Journal of Range Management 56:72-80.

Ansley, R. J., W. R. Teague, W. E. Pinchak, B. A. Kramp, and K. Barnett. 2010. Integrated grazing and prescribed fire restoration strategies in a mesquite savanna: II. Fire behavior and mesquite landscape cover responses. Rangeland Ecology \& Management 63:286-297.

Ansley, R. J., X. B. Wu, and B. A. Kramp. 2001. Observation: long-term increases in mesquite canopy cover in a north Texas savanna. Journal of Range Management 54:171-176.

Archer, S., C. Scifres, C. R. Bassham, and R. Maggio. 1988. Autogenic succession in a subtropical savanna: conversion of grassland to thorn woodland. Ecological Monographs 58:111-127.

Asner, G. P., S. Archer, R. F. Hughes, R. J. Ansley, and C. A. Wessman. 2003. Net changes in regional woody vegetation cover and carbon storage in Texas drylands, 1937-1999. Global Change Biology 9:316-335.

Bowen, M. W., W. C. Johnson, S. L. Egbert, and S. T. Klopfenstein. 2010. A GISbased approach to identify and map playa wetlands on the High Plains, Kansas, USA. Wetlands 30:675-684.

Browning, D. M., S. R. Archer, G. P. Asner, M. P. Mcclaran, and C. A. Wessman. 2008. Woody plants in grasslands: post-encroachment stand dynamics. Ecological Applications 18:928-944

Browning, D. M., S. R. Archer, and A. T. Byrne. 2009. Field validation of 1930s aerial photography: what are we missing? Journal of Arid Environments 73:844-853

Buffington, L. C., and C. H. Herbel. 1965. Vegetational changes on a semi-desert grassland range from 1858 to 1963. Ecological Monographs 35:139-164.

Byers, J. E., S. Reichard, J. M. Randall, I. M. Parker, C. S. Smith, W. M. Lonsdale, I. A. E. Atkinson, T. R. Seastedt, M. Williamson, E. Chornesky, and D. Hayes. 2002. Directing research to reduce the impacts of nonindigenous species. Conservation Biology 16:630-640.

Cabral, A. C., J. M. De Miguel, A. J. Rescia, M. F. Schmitz, and F. D. Pineda. 2003. Shrub encroachment in Argentinean savannas. Journal of Vegetation Science 14:145-152.

Canfield, R. H. 1941. Application of line interception in sampling range vegetation. Journal of Forestry 39:388-394.

Castillejo-González, I. L., F. López-Granados, A. Garcia-Ferrer, J. M. Peña-Barragán, M. Jurado-Expósito, M. S. De La Orden, and M. González-Audicana. 2009. Objectand pixel-based analysis for mapping crops and their agro-environmental associated measures using QuickBird imagery. Computers and Electronics in Agriculture 68:207-215
Congalton, R. G. 1991. A review of assessing the accuracy of classifications of remotely sensed data. Remote Sensing of Environment 37:35-46.

Congalton, R. G., and K. Green. 2009. Assessing the accuracy of remotely sensed data: principles and practices. 2nd ed. Boca Raton, FL, USA: Lewis Publishers. $179 p$.

Crimmins, S. M., A. R. Mynsberge, and T. A. Warner. 2009. Estimating woody browse abundance from aerial imagery. International Journal of Remote Sensing 30:3283-3289.

Davies, K. W., S. L. Petersen, D. D. Johnson, D. B. Davis, M. D. Madsen, D. L. Zvirzoin, AND J. D. BATES. 2010. Estimating juniper cover from National Agricultural Imagery Program (NAIP) imagery and evaluating relationships between potential cover and environemental variables. Rangeland Ecology \& Management 63:630-637.

Dinger, J. S., D. P. Zourarakis, and J. C. Currens. 2006. Spectral enhancement and automated extraction from Kentucky's NAIP imagery of potential sinkhole features, Trigg County, Kentucky, USA-initial investigation. Environmental Informatics Archives 4:312-323.

Enwright, N., M. G. Forbes, R. D. Doyle, B. Hunter, and W. Forbes. 2011. Using geographic information systems (GIS) to inventory coastal prairie wetlands along the upper Gulf Coast, Texas. Wetlands 31:687-697.

Everitt, J. H., C. Yang, M. A. Alaniz, M. R. Davis, F. L. Nibling, and C. J. Deloach. 2004. Canopy spectra of giant reed and associated vegetation. Journal of Range Management 57:561-569.

Everitt, J. H., C. Yang, and H. B. Johnson. 2007. Canopy spectra and remote sensing of Ashe juniper and associated vegetation. Environmental Monitoring and Assessment 130:403-413.

Fensham, R. J., And R. J. FalRfax. 2002. Aerial photography for assessing vegetation change: a review of applications and the relevance of findings for Australian vegetation history. Australian Journal of Botany 50:415-429.

Fensham, R. J., R. J. Fairfax, J. E. Holman, and P. J. Whitehead. 2002. Quantitative assessment of vegetation structural attributes from aerial photography. International Journal of Remote Sensing 23:2293-2317.

Foody, G. M. 2002. Status of land cover classification accuracy assessment. Remote Sensing of Environment 80:185-201.

Goslee, S. C., K. M. Havstad, D. P. C. Peters, A. Rango, and W. H. Schlesinger. 2003. High-resolution images reveal rate and pattern of shrub encroachment over six decades in New Mexico, USA. Journal of Arid Environments 54:755-767.

Heaton, C. B., X. B. Wu, and R. J. Ansley. 2003. Herbicide effects on vegetation spatial patterns in a mesquite savanna. Journal of Range Management 56:627-633.

Joshi, C., J. De Leeuw, and I. C. Van Duren. 2004. Remote sensing and GIS applications for mapping and spatial modeling of invasive species. In: A. Mo [ED.]. Proceedings of the XXth ISPRS Congress 2004. Istanbul, Turkey: ISPRS Press. p. 669-677.

Kadmon, R., and R. Harari-Kremer. 1999. Studying long-term vegetation dynamics using digital processing of historical aerial photographs. Remote Sensing of Environment 68:164-176.

Laliberte, A. S., A. Rango, J. E. Herrick, E. L. Fredrickson, and L. Burkett. 2007. An object-based image analysis approach for determining fractional cover of senescent and green vegetation with digital plot photography. Journal of Arid Environments 69:1-14.

LillesAnd, T. M., AND R. W. KiefER. 1994. Remote sensing and image interpretation. New York, NY, USA: John Wiley \& Sons, Inc. 750 p.

Lu, D., and Q. Weng. 2007. A survey of image classification methods and techniques for improving classification performance. International Journal of Remote Sensing 28:823-870.

MacDonald, I. A. W. 1989. Man's role in changing the face of southern Africa. In: B. J. Huntley [ED.]. Biotic diversity in southern Africa: concepts and conservation. Capetown, South Africa: Oxford University Press. p. 51-77.

Marsett, R. C., J. Qı, P. Hellman, S. H. Biedenbender, M. C. Watson, S. Amer, M. Weltz, D. Goodrich, and R. Marsett. 2006. Remote sensing for grassland management in the arid southwest. Rangeland Ecology \& Management 59:530-540

Martin, S. C., and R. M. Turner. 1977. Vegetation change in the Sonoran desert region, Arizona and Sonora. Journal of Arizona Academy of Sciences 12:59-69. 
Medlin, C. R., D. R. Shaw, P. D. Gerard, and F. E. Lamastus. 2000. Using remote sensing to detect weed infestations in Glycine max. Weed Science 48: 393-398.

Mihalik, E. N., N. S. Levine, And D. M. Amatya. 2008. Rainfall-runoff modeling of the chapel branch creek watershed using GIS-based rational and SCS-CN methods. ASABE Annual International Meeting, 29 June-2 July 2008, Providence, RI, USA. Paper number: 083971, p. 2726-2740.

Mirik, M., D. C. Jones, J. A. Price, F. Workneh, R. J. Ansley, and C. M. Rush. 2011. Satellite remote sensing of wheat infected by wheat streak mosaic virus. Plant Disease 95:4-12.

Pal, M., and P. M. Mather. 2004. Assessment of the effectiveness of support vector machines for hyperspectral data. Future Generation Computer Systems 20:1215-1225.

RICHARDS, J. A., AND X. JIA. 2006. Remote sensing digital image analysis: an introduction. Berlin, Germany: Springer-Verlag. 439 p.

Robinson, T. P., R. D. Van Klinken, and G. Metternicht. 2008. Spatial and temporal rates and patterns of mesquite (Prosopis species) invasion in Western Australia. Journal of Arid Environments 72:175-188.

[SCS] Soll Conservation Service. 1988. Texas brush inventory. Temple, TX, USA: United States Department of Agriculture, Soil Conservation Service Misc. Report. $89 \mathrm{p}$.

Sharma, R., and K. M. M. DakSHINI. 1991. A comparative assessment of the ecological effects of Prosopis cineraria and $P$. juliflora on the soil of revegetated spaces. Vegetatio 96:87-96.

Sharp, B. R., AND D. M. J. S. Bowman. 2004. Net woody vegetation increase confined to seasonally inundated lowlands in an Australian tropical savanna, Victoria River District, Northern Territory. Australian Ecology 29:667-683.

SноRт, N. M. 2011. Remote sensing tutorial. NASA online publication. Available at: http://rst.gsfc.nasa.gov. Accessed 26 April 2011.
Simth, H. N., and C. A. Rechenthin. 1964. Grassland restoration-the Texas brush problem. Temple, TX, USA: United States Department of Agriculture, Soil Conservation Service Misc. Report. 33 p.

SwaIN, P. H., AND S. M. Davis. 1978. Remote sensing: the quantitative approach. New York, NY, USA: McGraw-Hill. 405 p.

Thomlinson, J. R., P. V. Bolstad, and W. B. Cohen. 1999. Coordinating methodologies for scaling landcover classifications from site-specific to global: steps toward validating global map products. Remote Sensing of Environment 70:16-28.

Turner, W., S. Spector, N. Gardiner, M. Fladeland, E. Sterling, and M. Steininger. 2003. Remote sensing for biodiversity science and conservation. Trends in Ecology and Evolution 18:306-314.

van Klinken, R. D., and S. D. Campbell. 2001. Australian weeds series: Prosopis species. Plant Protection Quarterly 16:2-20.

van Klinken, R. D., D. Shepherd, R. Parr, T. P. Robinson, and L. Anderson. 2007. Mapping mesquite (Prosopis) distribution and density using visual aerial surveys. Rangeland Ecology \& Management 60:408-416.

Warren, A., J. Holechek, and M. Cardenas. 1996. Honey mesquite influences on Chihuahuan desert vegetation. Journal of Range Management 49:46-52.

Yang, C., J. H. Everitt, and H. B. Johnson. 2009. Applying image transformation and classification techniques to airborne hyperspectral imagery for mapping Ashe juniper infestations. International Journal of Remote Sensing 30:2741-2758.

Zourarakis, D. P., A. Brenner, B. Noyle, M. Palmer, R. Singh, S. A. Bacharach, and G. R. HARP. 2006. Kentucky's on-line bi-temporal land cover change and image comparison tool: the Kentucky landscape sensus portal (KLC). Environmental Informatics Archives 4:335-342. 